DOI: https://doi.org/10.35387/ucj.1(3).2021.45-50

VALENTYNA ANTONENKO

\title{
INNOVATIVE CULTURE DEVELOPMENT OF TEACHERS AND PUPILS AS A PEDAGOGICAL IDEA REALIZATION OF THE AUTHOR SCHOOL ON LINGUISTICS AND SPIRITUALITY
}

\begin{abstract}
The article presents theoretical and methodological, organizational and pedagogical principles of innovative culture of teachers and pupils as a realization of the pedagogical idea of the author's school of linguistics and spirituality of Zarifa Aliieva Irpin specialized secondary school I-III Grades №12 with foreign languages (school of linguistics) of Kyiv region; The author's school model is seen as a prototype of qualitative changes in education, which depends on a team of professionals who expand the space of educational opportunities for pupils development. The leading idea of the Author's School of Linguistics and Spirituality is the formation of a competitive, socially mobile, innovative, tolerant and spiritual personality. Gradually realizing this goal, the teaching staff made every effort to create a positive image of the educational institution, which determines: the presence of a relevant concept of the school of linguistics; implementation of long-term educational strategy; development of innovative culture of teachers and pupils; favorable moral and psychological climate in the team; availability of proper modern material and technical base; caring highly professional teaching staff; functioning of the school pupils organization «Country Roxolania». The introduction of the pedagogical idea of the author's school of linguistics and spirituality in the context of the development of innovative culture of teachers and pupils is based on current regulations. Personal and professional characteristics of a teacher with a high level of innovation culture (stable interest in technological innovation, motivation for creative activity, self-improvement and self-realization in professional activities, overcoming difficulties in innovation; values of professional self-expression in innovation, psychological attitude to innovation; innovative technologies, understanding the goals of innovation in education, knowledge of modern innovations in the practice of working with pupils).
\end{abstract}

Key words: innovative culture, teachers, pupils, author's school of linguistics and spirituality.

\section{РОЗВИТОК ІННОВАЦІЙНОЇ КУЛЬТУРИ ВЧИТЕЛІВ ТА УЧНІВ ЯК РЕАЛІЗАЦІЯ ПЕДАГОГІЧНОЇ ІДЕЇ АВТОРСЬКОЇ ШКОЛИ ЛІНГВІСТИКИ ТА ДУХОВНОСТІ}

Анотація. У статті представлено теоретико-методологічні, організаційно-педагогічні засади розвитку інноваційної культури вчителів та учнів як реалізація педагогічної ідеї авторської школи лінгвістики та духовності роботи Ірпінської спеціалізованої загальноосвітньої школи I-ІІІ ступенів №12 з вивченням іноземних мов (школи лінгвістики) імені Заріфи Алієвої Ірпінської міської ради Київської області; Модель авторської школи розглядається як прообраз якісних перетворень в освіті, що залежить від команди професіоналів, які розширюють простір освітніх можливостей для розвитку дитини. Провідною ідеєю Авторської школи лінгвістики і духовності є формування конкурентоспроможної, соціально мобільної, інноваційної, толерантної та духовної особистості. Реалізуючи поступово цю мету, педагогічний колектив доклав максимум зусиль для створення позитивного іміджу закладу освіти, що визначають: наявність актуальної концепції школи лінгвістики; втілення довгострокової освітньої стратегії; розвитку інноваційної культури вчителя та учнів; сприятливий морально-психологічний клімат у колективі; наявність належної сучасної матеріально-технічної бази; небайдужий високопрофесійний педагогічний колектив; функціонування шкільної учнівської організації «Країна Роксоланія». Упровадження педагогічної ідеї авторської школи лінгвістики та духовності в контексті розвитку інноваційної культури вчителів та учнів відбувається на основі чинних нормативно-правових документів. Розглядаються особистісні і професійні характеристики вчителя з високим рівнем інноваційної культури (стійкий інтерес до технологічних інновацій, мотивація творчої активності, самовдосконалення та самореалізації у професійній діяльності, подолання труднощів в інноваційній діяльності; цінності професійного самовираження в інноваційній діяльності, психологічної установки на інноваційну діяльність; знання про інноваційні технології, розуміння цілей інноваційної діяльності в освіті, знання сучасних інновацій у практиці роботи з учнями).

Ключові слова: інноваційна культура, вчителі, учні, авторська школа лінгвістики та духовHOCmi.

Introduction. The Modernization of the national education system in the context of social requirements needs a reform of its structure and content. One of the key stages of reforming 
the national education system is the study of the essence and features of the implementation of teacher's innovative activities, the structural element of which is innovative culture. Innovative activity requires from teachers a new way of thinking, a new perception of the pedagogical process. The changes taking place in modern society require from the teacher the qualities that allow responding creatively and productively to it. It is the combination of problems caused by different degrees of readiness and practical use of innovation by individual educators that researchers are increasingly associating with the concept of innovation culture (Sydorenko, 2014).

Innovative culture is a relatively new concept. The emergence of innovative culture in the culturogenesis is a natural and historically determined phenomenon. Studies of previous decades show that scientists are interested in innovative culture as a form of organizational culture that emerged in the late of XX century as an adaptation to the acceleration of changes in society, which ensures the development of society through innovative solutions. The components of innovative culture cover aspects of the teacher's mastery of new pedagogical values, technologies of pedagogical activities, ways of professional interaction in new conditions, the level of participation in information exchange and new opportunities for professional and creative self-realization (Sydorenko, 2014).

Teacher innovative culture as a professional phenomenon is realized on two levels: at the level of the individual and at the level of the specialist. At the individual level, innovative culture is an element of spiritual life that reflects the value orientation of the teacher, enshrined in motives, competencies, patterns and norms of behavior, and ensures his receptivity to new ideas, his/her willingness and ability to support and implement innovations in all spheres of life. At the professional level, the innovative culture of the teacher characterizes the high level of his/her pedagogical activity (Tsurkan, 2020).

The aim of the study is to highlight the main statements for the innovative culture development of teachers and pupils as the pedagogical idea implementation of the author's school of linguistics and spirituality in Zarifa Aliieva Irpin Specialized Secondary School of I-
III Grades №12 with foreign languages (school of linguistics).

Theoretical basis and research methods. To achieve the aim of the study, the following methods were used: analysis, synthesis, generalization, which revealed the features of innovative culture of teachers and pupils to implement the pedagogical idea of the author's school of linguistics and spirituality; methods of extrapolation and prognosis, which helped to determine the prospects for the use of progressive ideas of the author's school of linguistics and spirituality in the development of teachers and pupils innovative culture at Zarifa Aliieva Irpin Specialized Secondary School of I-III Grades №12 with foreign languages (school of linguistics).

Results. We are aware of nowadays modern requirements for the development of innovative culture. That is why Zarifa Aliieva Irpin Specialized Secondary School of I-III Grades №12 with foreign languages (school of linguistics) pays special attention to the development of teacher's innovative culture in connection with rethinking the principles of educational process as a pedagogical idea of the School of Linguistics and Spirituality.

The development of innovative culture of both teachers and pupils is one of the main components of the general culture of the individual, built on a certain system of values and ideals, the principles of innovative model of human behavior. In the author's School of Linguistics and Spirituality it is realized through the systematic formation of the value consciousness of the individual as a carrier, creator and substrate of culture through the full inclusion of psychological mechanisms of individual integration into the cultural innovation environment (Antonenko, 2019).

In order to effectively implement the peculiarities of the development of innovative culture of both teachers and pupils in 2019, the manual "Author's School of Linguistics and Spirituality» was published, and recommended for publication by the Academic Council of the Ivan Ziaziun Institute of Pedagogical Education and Adult Education of NAES of Ukraine. In the manual were presented organizational, pedagogical and innovative principles of the school, also presented the program of the author's School of Linguistics and Spirituality development, highlights its history and nowadays. 
The author's idea of the School of Linguists and Spirituality has been implemented since 2001. During this time we have developed and implemented:

- Author's Concept of educational school development;

- Author's Model of school development;

- Author's Model of international activity management;

- Author's Model of specialize education training;

- Author's Model of organizational and managerial activity.

- Author's Model of teachers and pupils innovative activity development.

Author's School of Linguistics and Spirituality is a model of an educational institution in which the content of education and the system of relations at the level of «teacher-pupil», «pupil-pupil», «teacher-teacher», «teacher-parentspupil». In order to create and provide conditions for stable innovative development, which is characterized by searches and original approaches.

We consider the innovative culture of teachers in our School of Linguistics and Spirituality as a set of interconnected (Bartkiv, 2010) components: competence-based, axiological, innovation-technological, cooperative-activity, communicative, personal-creative. Briefly describe these components.

Competence-based component involves the availability and development of specific professional competencies that teachers use in their professional activities and in working with pupils.

The axiological component of the teacher innovative culture is a set of pedagogical values, ie professionally significant knowledge that is constantly updated, ideas, beliefs of the teacher.

The innovation-technological component combines the methods of innovationpedagogical activity that provide solutions to the problems of innovation management and self-government of innovation-pedagogical activities, which include: analytical-reflective tasks; constructive and prognostic; organizational and active; evaluation and information; corrective and regulatory.

The cooperative-activity component reflects the culture of cooperation of teachers in joint innovation activities.
The communicative component determines the culture of teacher participation in information exchange.

The personal-creative component provides interpretation of pedagogical innovations in individual pedagogical activity of the teacher: creation of own innovative experience, adaptation of borrowed experience to concrete conditions, professional-personal self-realization of the teacher in innovative activity, consideration of needs and possibilities of pupils, etc.

One of the priorities of the author's School of Linguistics and Spirituality is to take care of gifted pupils. After all, it is the potential of the State that will determine the ways of its development in the future. To this end, we set ourselves the task of creating the most favorable conditions for intellectual, moral, physical and innovative development of gifted children, the formation of skills to use their mental potential in practice.

That is why, projecting the author's vision of the school, as part of the experimental work we created conditions for pupils to learn 12 foreign languages: Ukrainian, Russian, Polish, English, French, German, Chinese, Japanese, Arabic, Italian, Spanish, Persian, which is the key creation in the future on the basis of the school of three centers for the languages study: Slavic, Romano-Germanic and Oriental languages - the prototype of the school of the future. Aware of the responsibility for the results of our own professional activities, we maintain close long-term contacts with the embassies of the countries whose languages are studied by pupils (Antonenko, 2019).

Innovative and spiritual development of pupils is supported by the school student organization «Country Roxolania» - the winner of the All-Ukrainian competition for the best model of pupil government. The main mission is social and pedagogical support of pupils, aimed not only at honoring and continuing the traditions of the Ukrainian people, conducting a program of events «With Ukraine in the heart», but also mastering modern innovative tools for learning and self-development.

Innovative techniques, skills and abilities of a teacher are necessary for training and conducting active forms of classes with pupils, establishing innovative activities in school, using technical means in organizing and conducting classes, developing plans, forms, methods and recommendations for innovation, analysis of 
innovation processes in educational process, etc.

The innovative creative potential of teachers is confirmed by the fact that $71 \%$ of teachers have the highest qualification category and pedagogical titles. Among the pedagogical staff of the school: 1 - Honored Teacher of Ukraine, 11 - «Excellence in Education of Ukraine», 25 teachers-methodologists, 21 - senior teachers, 64 - teachers of the highest qualification category, 14 have the first category, 18 - the second, 14 - specialists (Antonenko, 2019).

It is especially worth noting the high professionalism of the administrative team of the school: deputy director for educational activities, deputy director for foreign languages, teacher-organizer. The specificity of their contribution to the development of innovative culture of the educational institution is to ensure a clear organization of the team in accordance with the concept of school activities and modern requirements of nowadays. The most important task of their management is the transition of the traditional educational system to the mode of innovation-cultural and educational environment (Antonenko, 2019).

Among the significant achievements of the author's School of Linguistics and Spirituality we want to highlight the following:

- The school is a participant in the experiment to test the new State Standard of Primary General Education at the All-Ukrainian level (New Ukrainian School) (from 2017-2021 academic year);

- Participant in the All-Ukrainian scientific and pedagogical project «Intellect of Ukraine», which taught 14 classes from 2012-2013 academic year;

- Cambridge University School in Ukraine (based on the signed Memoranda of Cooperation 2013, 2018);

- Pearson's partner (based on an agreement with the Pearson Education International Group (UK)) since 2016;

- The school has twice been awarded the international award «School-eTwinning» (from 2017-2018 academic year).

A significant achievement of the school teaching staff is the diploma of the International Academic Rating of Popularity «Golden Fortune» and the honorary award «Labor Glory» (2011). Valuable are the awards won by the school teaching staff, participating in nine in- ternational exhibitions «Modern educational institutions» ( 2 silver and 5 gold medals) in the nominations:

- High creative achievements in innovative renewal of the national education system;

- Introduction of innovative pedagogical technologies into the educational process of the school;

- International cooperation of educational institutions and research institutions;

- Active introduction of innovative educational technologies, fruitful scientific and pedagogical activities on innovative modernization of education;

- Significant contribution to the development of national education;

- International cooperation as an integral part of innovative development of national education;

Development and implementation of innovative projects, training technologies, programs and solutions to modernize the educational process and increase the level of knowledge of young people;

Realizing our own innovation potential (Antonenko, 2019), we have achieved stable positive results, high level of competitiveness, as: 23 years in a row the school wins first place in the second (city) stage of the All-Ukrainian Olympiads in basic disciplines; for the last 5 academic years we have 21 winners and 67 prize-winners of the third (regional) stage of the All-Ukrainian Olympiads in basic disciplines;

Six-year cooperation of the School with European educational institutions in eTwinning platform international projects. During this time, we have implemented 17 projects on various topics: «Ecology, bullying, culture, traditions, life of people with special needs», as a result, five times our school was awarded the All-Ukrainian award for best project of the year;

Partnership of the School with the Peace Corps (pupils took a course «Financial Literacy», conducted by a volunteer from the United States, Mr. William Olsen, and were active participants in online meetings with ambassadors of Austria, Norway and Brazil on «Local Studies» and «Education»;

Registration of the School on the Civilportal platform from the Civic Education Laboratory «Search» of the Lion Society (Lviv, Ukraine) and 
the Education for Democracy Foundation (Warsaw, Poland), which provides cooperation in international projects with Polish schools. In 2020-2021, we signed an agreement on cooperation with the Goethe Institute in the preparation and conduct of German language exams for international certificates, participation in events, trainings, competitions that will take place on its basis;

Preparation for the selection competition in 2021-2022 academic year for membership in the project PASCH-SCHULEN - «Schools - partners of the future», which offer various motivating projects and activities for pupils and teachers;

Application of various innovative platforms on which we cooperate in many international projects: CIVIL MATCH (Ukrainian-German journalistic project); eTwinning (WONDERFUL KIDS project); KNOW MY WORLD (UkrainianAmerican project «We are the World. We are Equel»); FLEX (American exchange program) (we have three winners of this program, who had the opportunity to study for a year in USA) etc.;

Teachers of the school regularly participate in various workshops, congresses, webinars, seminars from international organizations (Cambridge - Oxford - Maccmillan - Dinternal Publishing, Go Gamp, EdCamp, Fundacio'n Varkey).

Conclusions. Thus, in order to improve and develop the innovative educational space of the School, as well as the innovative culture of teachers and pupils through the widespread implementation of IT technologies to increase the professional competence of teachers, directing their work to realize creative potential, involving teachers and pupils in project, research, experimental and innovative activities, the following areas of further work have been developed:

1. Improving the skills of teachers by improving the use in educational practice of mul- timedia IT support, their own educational ematerials and information from the global Internet, as well as the use of interactive technologies for teaching and educating pupils.

2. Software and methodological support of the educational process, development of multilevel, differentiated programs, teaching aids for teachers and pupils.

3. Cooperation of the School with scientific institutions, educational institutions of different levels of accreditation, NGOs, foreign schools.

4. Involvement of specialists, as mentorsconsultants, in the field of comparative studies on the use of developed countries experience in the development of innovative culture and activities of teachers and pupils.

5. Development and implementation of mechanisms to attract additional financial and material resources for the full operation of the School in accordance with modern requirements of nowadays (targeted social projects, investments, charitable contributions, etc.).

6. Expansion of the specialized classes network, where pupils study according to the scientific and pedagogical project «Intellect of Ukraine» and partial use of bilingual education in lessons of physics, chemistry, mathematics;

7. Ensuring compliance with the principle of responsibility of the educational institution for the results of educational activities with the active involvement of the parent community and the School Board.

8. Increasing the level of organization, training and conduct of research and innovation activities of teachers and pupils in order to receive competitive grants.

As a result, we can say that the native and foreign policy of our author's School of Linguistics and Spirituality, aimed at forming an innovative cultural environment, which is to promote the innovative culture of teachers and pupils, and the orientation of the educational process principles of State innovation policy.

\section{REFERENCES}

Antonenko, V.S. (2019). Author's School of Linguistics and Spirituality: a manual. Kyiv. LLC «DKS Center». Bartkiv, O. (2010). Readiness of the teacher for innovative professional activity. Problems of modern teacher training, 1, 52-58.

Mylenkova, R.V. (2008). Innovative culture: a new approach to the development of modern personality, school, society. Pedagogical sciences: a collection of scientific articles, 1, 133-142.

Sydorenko, N.V. (2014). Innovative culture as the highest manifestation of general cultural professional and personal qualities of a teacher. Pedagogical sciences: theory, history, innovative technologies, 3(37), 337-346. 
Tsurkan, T.H. (2020). Innovative culture of the teacher of the New Ukrainian School. Pedagogy of creative personality formation in higher and general education schools, 68, 1, 128-132. DOI https://doi.org/10.32840/1992-5786.2020.68-1.26

Валентина Антоненко, директор Ірпінської спеціалізованої загальноосвітньої школи I-III ступенів №12 з вивченням іноземних мов (школа лінгвістики) імені Заріфи Алієвої Ірпінської міської ради Київської області, Заслужений працівник освіти України.

Valentyna Antonenko, Director of Zarifa Aliieva Irpin Specialized Secondary School of I-III Grades №12 with the Study of Foreign Languages (School of Linguistics) of the Irpin City Council of Kyiv Region, Honored Education Worker of Ukraine.

E-mail: school12 irpin@ukr.net

Received: 05.10.2021

Accepted: 22.10.2021 